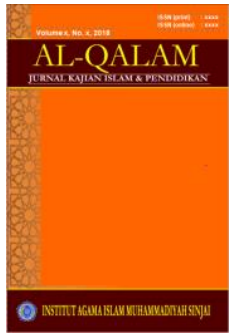

\title{
PENDIDIKAN ISLAM SEBAGAI PEWARISAN NILAI-NILAI DAN BUDAYA
}

Oleh : $A l$ Amin $^{1}$

\begin{abstract}
Abstrak
Dunia pendidikan tidak terlepas dari internalisasi nilai-nilai dan budaya. Dimana ruh dari pendidikan itu adalah penanaman dan pewarisan nilai budaya. Tanpa nilai budaya tidak mungkin lahir suatu kepribadian. Kepribadian seseorang terbentuk karena adanya nilainilai budaya di mana seseorang dilahirkan, dibesarkan, dan dididik dalam lingkungan pendidikan, baik dari lingkungan keluarga, sekolah, maupun lingkungan sosial masyarakat. Jenis penelitian ini adalah studi pustaka (Library Research). Studipustaka yang dimaksud dalam penelitian ini yaitu penelitian yang pengumpulan datanya dilakukan dilapangan (Perpustakaan) dan menggali sumber data bukan dari manusia. Maka penulis mengkaji secara teoretis tentang pendidikan Islam dengan pewarisan nilai-nilai dan budaya dengan hasil nilai-nilai yang berkembang dalam masyarakat sepanjang tidak bertentangan dengan semangat ajaran Islam adalah termasuk nilainilai budaya yang perlu dilestarikan. Inti dari nilai-nilai itu sebenarnya tersimpul dalam al-akhlāq al-karīmah.
\end{abstract}

Kata Kunci : Pendidikan Islam, Pewarisan Nilai, Budaya

\section{PENDAHULUAN}

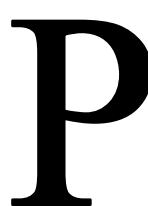

endidikan merupakan bagian penting dalam kehidupan manusia yang sekaligus membedakan manusia dengan hewan. Hewan juga belajar, tetapi lebih ditentukan oleh instingnya sedangkan bagi manusia belajar berarti rangkaian kegiatan menuju pendewasaan guna mencapai kehidupan yang lebih berarti. Oleh karena itu, pendidikan sebagai suatu aktivitas yang sadar akan tujuan, ia menempati posisi sentral dan startegis dalam membangun kehidupan sosial dan memposisikan manusia dalam pluralisme kehidupan secara tepat.

Demikian pula halnya dengan pendidikan Islam yang secara umum didefinisikan sebagai usaha untuk memelihara dan mengembangkan fitrah

\footnotetext{
${ }^{1}$ Dosen Tetap IAI Muhammadiyah Sinjai
} 


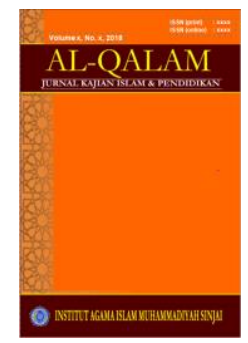

AL-QALAM

Jurnal Kajian Islam \& Pendidikan

Volume 10, No. 1, 2018

ISSN (print) : 1858-4152

ISSN (online) : xxxx-xxxx

Homepage : http://journal.iaimsinjai.ac.id/index.php/al-qalam

manusia serta segala sumber daya yang ada padanya menuju terbentuknya manusia yang paripurna sesuai dengan norma-norma Islam. Konsep manusia seutuhnya dalam persfektif Islam secara garis besarnya dapat dipormulasikan sebagai manusia yang beriman dan bertakwa serta memiliki ilmu pengetahuan dan segala bentuk kemampuan lainnya yang teraktualisasi dalam hubungannya dengan Tuhan, sesama manusia dan dengan alam sekitarnya secara baik, positif dan konstruktif. $^{2}$

Tujuan pendidikan itu mengarah pada perubahan perilaku dari tidak baik menjadi baik, dari negative menjadi positif, bukan sebaliknya. Sejak awal tumbuhnya kesadaran tentang adanya pendidikan dalam masyarakat telah diletakkan suatu prinsip dasar bahwa pendidikan dimaksudkan untuk menanamkan budaya dengan jalan mengajarkan anak-anak untuk mengetahui serta mengamalkan nilai-nilai, norma-norma, atau tata cara baik yang berlaku dalam masyarakat. ${ }^{3}$ Dari sini dipahami bahwa roh dari pendidikan itu adalah penanaman dan pewarisan nilai budaya. Kepribadian seseorang terbentuk karena adanya nilai-nilai budaya di mana seseorang dilahirkan, dibesarkan, dan dididik. Tanpa nilai budaya tidak mungkin lahir suatu kepribadian. ${ }^{4}$ Penulis mencoba mengkaji secara teoretis tentang pendidikan Islam dengan pewarisan nilai-nilai dan budaya yang akan dituangkan dalam pembahasan ini.

\section{METODE PENELITIAN}

Jenis penelitian ini adalah studi pustaka (Library Research). Studipustaka yang dimaksud dalam penelitian ini yaitu penelitian yang pengumpulan datanya dilakukan dilapangan (Perpustakaan) dan menggali sumber data bukan dari manusia. Sehingga dalam melakukan penelitian ini didasarkan atas pembacaan

\footnotetext{
${ }^{2}$ Achmadi, Pendidikan Islam sebagai Paradigma Ilmu Pendidikan (Cet. 1; Yogyakarta: Aditya Media, 1992) dalam Khaeruddin, Ilmu Pendidikan Islam: Mendesain Insan yang Hakiki dan Mengintip Muslimah dalam Sejarahnya (Makassar: Yayasan Pendidikan Fatiya, 2002), h. 26. 1992), h. 1-2.

${ }^{3}$ Hasan Langgulung, Asas-Asas Pendidikan Islam (Cet. II; Jakarta: Pustaka Al-Husna, 2004), h. 190.

${ }^{4}$ H.A.R. Tilaar, Paradigma Baru Pendidikan Nasional (Cet. II; Jakarta: Rineka Cipta,
} 


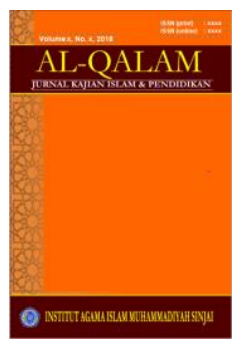

AL-QALAM

Jurnal Kajian Islam \& Pendidikan

Volume 10, No. 2, 2018

ISSN (print) : $1858-4152$

ISSN (online) : 2715-5684

Homepage : http://journal.iaimsinjai.ac.id/index.php/al-qalam

terhadap literature yang memiliki informasi dan memiliki relevansi dengan topic penelitian. Metode pengumpulan data menggunakan berbagai literatur yang berkaitan dengan penelitian ini. Adapun sumber data dalam penelitian ini berupa jurnal, laporan hasil penelitian, buku hasil seminar dan lain sebagainya yang memiliki relevansi dengan topic penelitian. Objek dalam penelitian ini yaitu berkaitan dengan variabel pendidikan Islam dengan pewarisan nilai-nilai dan budaya

\section{PEMBAHASAN}

\section{Nilai-Nilai dan Budaya yang Perlu Dipertahankan sebagai Hasil Warisan Pendidikan}

Nilai dan budaya sebagai warisan pendidikan perlu dipahami terlebih dahulu dari pengertiannya. Kata value,yang kemudian diterjemahkan ke dalam bahasa Indonesia menjadi nilai, berasal dari bahasa Latin yaitu valere, atau bahasa Prancis Kuno volair yang berarti (berguna, mampu akan, berdaya, berlaku, kuat). ${ }^{5}$ Dalam sudut pandangan filosofis, nilai sangat terkait dengan masalah etika. Etika juga sering disebut sebagai filsafat nilai, yang mengkaji nilai-nilai moral sebagai tolok ukur tindakan dan perilaku manusia dalam berbagai aspek kehidupannya. ${ }^{6}$ hal ini bisa dilihat dalam Kamus Besar Bahasa Indonesia, bahwa nilai merupakan sesuatu yang menyempurnakan manusia sesuai dengan hakikatnya, ini berhubungan erat dengan etika, yang artinya nilai untuk manusia sebagai pribadi yang utuh, misalnya kejujuran, nilai yang berhubungan dengan akhlak, nilai yang berkaitan dengan benar dan salah. ${ }^{7}$

Pengertian ini semakin diperkuat dalam Ensiklopedi Pendidikan diterangkan, bahwa nilai adalah filsafat tentang baik dan buruk, yang mengajarkan tentang keluruhan budi. ${ }^{8}$ Sedangkan menurut istilah nilai adalah studi tentang

${ }^{5}$ Lorenz Bagus, Kamus Filsafat (Cet. III; Jakarta: Gramedia, 2002),h. 713.

${ }^{6}$ Said Agil Husin Almunawar, Aktualisasi Nilai-Nilai Qurani dalam Sistem Pendidikan Islam (Cet. 1; Jakarta: Ciputat Press, 2003), h. 3.

${ }^{7}$ Tim Penyusun Kamus Pusat Bahasa, Kamus Besar Bahasa Indonesia (Cet. III; Jakarta: Balai Pustaka, 2005), h. 783.

${ }^{8}$ Soegarda Poerbawatja, Ensiklopedi Pendidikan(Jakarta: Gunung Agung, 1999), h. 82. 


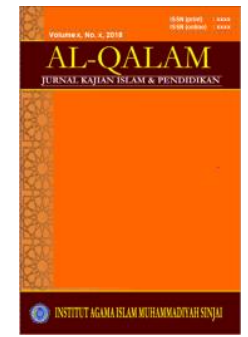

AL-QALAM

Jurnal Kajian Islam \& Pendidilkan

Volume 10, No. 1, 2018

ISSN (print) : 1858-4152

ISSN (online) : xxxx-xxxx

Homepage : http://journal.iaimsinjai.ac.id/index.php/al-qalam

tingkah laku manusia, tidak hanya menentukan kebenaran sebagaimana adanya, tetapi juga menyelidiki manfaat atau kebaikan dari seluruh tingkah laku manusia yaitu perilaku yang melandasi moralitas (akhlak). ${ }^{9}$ Pendapat yang lain mengartikan nilai adalah suatu keyakinan yang membuat seseorang bertindak atas dasar pilihannya. ${ }^{10}$ Sedangkan menurut Hans Jonas nilai adalah patokan normatif (pertimbangan tentang baik dan buruk, benar dan salah, haq dan batal, diridhai dan dikutuk oleh Allah) yang mempengaruhi manusia dalam menentukan pilihannya di antara cara-cara tindakan alternatif. ${ }^{11}$ Menurut hemat penulis, beberapa pengertian nilai di atas pada intinya bahwa nilai adalah rujukan dan keyakinan dalam menentukan suatu pilihan bagi seseorang, yang tercermin dalam pola pikir, tingkah laku, dan serta sikap. Seperti kejujuran, keadilan, kebenaran dijadikan sebagai pegangan dalam hidupnya.

Budaya yang lazim disebut kebudayaan atau sistem kebudayaan, berasal dari kata Sansakerta buddhayah, yaitu bentuk jamak dari buddhi yang berarti "budi" atau "akal". Dari pengertian kata budhi itulah, kebudayaan dapat diartikan sebagai "hal-hal yang bersangkutan dengan akal. ${ }^{12}$ Dalam definisi yang klasik tentang kebudayaan sebagaimana dikemukakan oleh Edward Burnett Tylor pada abad ke-19, secara jelas dinyatakan bahwa budaya merupakan suatu keseluruhan yang kompleks yang mencakup pengetahuan, keyakinan, kesenian, moral, hukum, adat istiadat dan segala kemampuan dan kebiasaan yang diperoleh manusia sebagai anggota masyarakat. ${ }^{13}$ Ki Hajar Dewantara dan kawan-kawan , mengemukakan budaya itu adalah gabungan dari dua kata "budi" dan "daya". Budi terletak di hati, daya terletak di perbuatan. Iman timbalan budi, amal

\footnotetext{
${ }^{9}$ Khaeruddin, Pemikiran Nilai dan Etika Pendidikan Islam (Cet. I; Makassar: Yayasan Pendidikan Makassar, 2003), h. 65.

h. 9. ${ }^{11}$ Rohmat Mulyana, Mengartikulasikan Pendidikan Nilai, h. 9.

${ }^{12}$ Redaksi Ensiklopedi Nasional, Ensiklopedi Nasional Indonesia, Jilid III (Cet. I; Jakarta: PT. Cipta Adi Pustaka, 1988), h. 495.

${ }^{13}$ Redaksi Ensiklopedi Nasional, Ensiklopedi Nasional Indonesia, h. 495.
} 


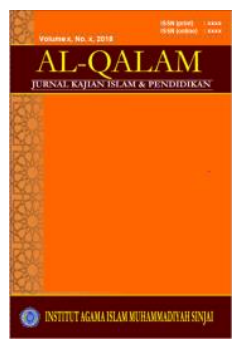

AL-QALAM

Jurnal Kajian Islam \& Pendidikan

Volume 10, No. 2, 2018

ISSN (print) : $1858-4152$

ISSN (online) : 2715-5684

Homepage : http://journal.iaimsinjai.ac.id/index.php/al-qalam

timbalan daya. ${ }^{14}$ Selanjutnya, dia mengatakan bahwa budaya merupakan wujud atau refleksi dari iman. Karena seorang muslim yang dalam agama ditaati segala perintahnya dan menjauhi segala larangan. Perbuatan karena iman itulah yang disebut amal saleh, sebab itu amal saleh meliputi dua bidang yaitu agama dan budaya. Tidaklah tepat untuk mengartikan budaya sebagai penjelmaan iman dan amal saleh, jika amal saleh itu kebudayaan dengan sendirinya agama termasuk dalam bidang budaya. ${ }^{15}$ Istilah nilai budaya di atas dapat dipahami sebagai suatu konsep abstrak mengenai masalah dasar yang sangat penting dan bernilai dalam kehidupan manusia. konsep tersebut dapat berupa nilai etik, seperti sopan santun, nilai-nilai tersebut tentunya yang sesuai dengan semangat ajaran Islam.

Terlepas dari pengertian di atas, selanjutnya bagaimana pendidikan Islam dikatakan sebagai pewarisan nilai-nilai dan budaya. Pada hakikatnya, dilihat dari segi idealitas sosio-kultural muslim, pendidikan adalah merupakan alat pembudayaan umat manusia yang paling diperlukan di antara keperluan hidupnya, meskipun pendidikan itu sendiri pada mulanya timbul dan berkembang dari sumber kultural umat itu sendiri. ${ }^{16}$

Sebagai suatu alat, maka pendidikan Islam harus memiliki watak lentur terhadap perkembangan aspirasi kehidupan manusia sepanjang zaman. Watak demikian dengan tanpa menghilangkan prinsip-prinsip nilai yang mendasarinya. Pendidikan Islam mampu mengakomodasikan tuntutan hidup manusia dari zaman ke zaman, termasuk tuntutan di bidang ilmu dan teknologi. ${ }^{17}$

Khusus berkaitan dengan tuntutan perkembangan ilmu dan teknologi, pendidikan Islam, bersikap mengarahkan dan mengendalikannya, sehingga nilai fundamental yang bersumber dari iman dan takwa kepada Allah., dapat berfungsi

\footnotetext{
${ }^{14}$ Sidi Gazalba, Asas Kebudayaan Islam Pembahasan Ilmu dan Filsafat tentang Ijtihad, Fiqih,Akhlak, Bidang-bidang Kebudayaan, Masyarakat, Negara (Cet. I; Jakarta: Bulan Bintang, 1978), h. 169.

${ }^{15}$ Sidi Gazalba, Asas Kebudayaan Islam Pembahasan Ilmu dan Filsafat tentang Ijtihad, Fiqih,Akhlak, Bidang-bidang Kebudayaan, Masyarakat, Negara, h. 169.

${ }^{16}$ M. Arifin, Filsafat Pendidikan Islam (Cet. IV; Jakarta: Bumi Aksara, 1994), h. 36.

${ }^{17}$ Nasir A. Baki, Filsafat Pendidikan Islam (Cet. I; Makassar: Alauddin University Press, 2013), h.105.
} 


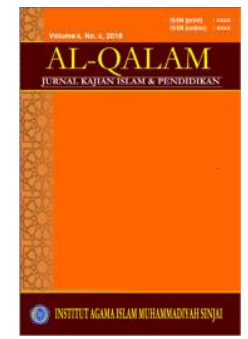

AL-QALAM

Jurnal Kajian Islam \& Pendidilkan

Volume 10, No. 1, 2018

ISSN (print) : 1858-4152

ISSN (online) : xxxx-xxxx

Homepage : http://journal.iaimsinjai.ac.id/index.php/al-qalam

dalam kehidupan manusia yang telah menciptakan ilmu dan teknologi itu. Iman dan takwanya menjiwai ilmu dan teknologi yang diciptakan, sehingga penggunaannya pun diarahkan kepada upaya menciptakan kesejahteraan hidup umat manusia, bukan untuk menghancurkannya. ${ }^{18}$ Karena iman dan takwa kepada Allah pada hakikatnya merupakan rujukan tingkah laku manusia yang memancarkan getaran hati nurani manusia yang berkecenderungan kearah perikemanusiaan. Dengan demikian, manusia muslim hasil pendidikan adalah manusia yang berkemampuan menguasai dan menciptakan ilmu dan teknologi pada khususnya, dan sistem budaya hidupnya berdasarkan nilai-nilai islami yang berorientasi kepada kesejahteraan hidup di dunia untuk meraih kebahagiaan hidup di akhirat.

Ada tiga dimensi kehidupan manusia yang mengandung nilai ideal Islami yang dijadikan dasar fundamental dari proses pendidikan Islam yaitu:

1. Dimensi yang mengandung nilai yang meningkatkan kesejateraan hidup manusia di dunia. Dimensi nilai kehidupan ini mendorong kegiatan manusia untuk mengelola dan memanfaatkan dunia ini agar menjadi bekal/sarana bagi kehidupan di akhirat.

2. Dimensi yang mengandung nilai yang mendorong manusia berusaha keras untuk meraih kehidupan di akhirat yang membahagiakan. Dimensi ini menuntut manusia untuk tidak terbelenggu oleh rantai kekayaan duniawi atau materi yang dimiliki, namun kemelaratan atau kemiskinan dunia harus diberantas, sebab kemelaratan duniawi bisa menjadi ancaman yang menjerumuskan manusia kepada kekufuran.

3. Dimensi yang mengandung nilai yang dapat memadukan antara kepentingan hidup duniawi dan ukhrawi. Keseimbangan dan keserasian antara kedua kepentingan hidup ini menjadi daya tangkal terhadap pengaruh-pengaruh negatif dari berbagai gejolak kehidupan yang menggoda ketenangan hidup

\footnotetext{
${ }^{18}$ M. Arifin, Filsafat Pendidikan Islam h. 37
} 


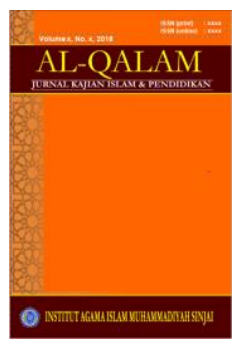

AL-QALAM

Jurnal Kajian Islam \& Pendidikan

Volume 10, No. 2, 2018

ISSN (print) : $1858-4152$

ISSN (online) : 2715-5684

Homepage : http://journal.iaimsinjai.ac.id/index.php/al-qalam

manusia, baik yang bersifat spiritual, sosial, kultural, ekonomis, maupun ideologis dalam hidup pribadi manusia. ${ }^{19}$

Dimensi-dimensi nilai di atas merupakan sasaran idealitas islami yang seharusnya dijadikan dasar fundamental dari proses kependidikan Islam. Dimensidimensi nilai tersebut seharusnya ditanam-tumbuhkan di dalam pribadi muslim secara seutuhnya melalui proses pembudayaan yang bercorak pendidikan, dengan sistem atau struktur kependidikan yang bagaimanapun bentuknya. Di sinilah kita melihat bahwa, dimensi nilai-nilai Islami yang menekankan keseimbangan dan keselarasan hidup duniawi-ukhrawi, menjadi landasan ideal yang hendak dikembangkan atau dibudayakan dalam pribadi manusia melalui pendidikan sebagai alat pembudayaan.

Nilai-nilai islami yang fundamental yang mengandung kemutlakan bagi kehidupan manusia, selaku pribadi dan selaku anggota masyarakat tidak berkecenderungan untuk berubah mengikuti selera nafsu manusia yang berubahubah sesuai tuntutan itu, sebaliknya akan berfungsi sebagai pengendali atau pengarah terhadap tuntutan perubahan sosial dan tuntutan individual. ${ }^{20}$ Di sinilah tugas pendidikan Islam, untuk dapat mempertahankan, menanamkan, dan mengembangkan kelangsungan berfungsinya nilai-nlai Islam yang bersumber dari Alquran dan Hadis. Dan sejalan dengan tuntutan kemajuan kehidupan masyarakat akibat pengaruh kebudayaan yang meningkat. ${ }^{21}$

Terlaksananya peningkatan kebudayaan masyarakat dalam pendidikan Islam, maka tujuan dari pendidikan Islam akan tercapai. Artinya seseorang yang berhasil dididik menjadi muslim, sudah barang tentu memiliki dalam pribadinya suatu pola hidup yang diwarnai oleh nilai-nilai islami secara utuh dan bulat. Nilainilai itu akanterealisasi dalam perilaku kehidupan lahiriah sebagai refleksi dari perilaku batiniahnya. Perilaku batiniahnya senantiasa berorientasi kepada normanorma ajaran Islam yang mengacu kedalam nilai-nilai islami yang membentuk

${ }^{19}$ M. Arifin, Filsafat Pendidikan Islam, h. 120.

${ }^{20}$ Nasir A. Baki, Filsafat Pendidikan Islam, h.113.

${ }^{21}$ M. Arifin, Filsafat Pendidikan Islam, h. 121. 


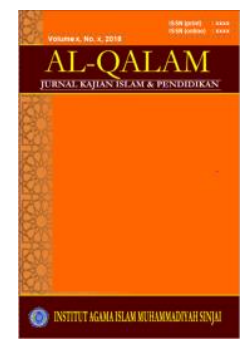

AL-QALAM

Jurnal Kajian Islam \& Pendidikan

Volume 10, No. 1, 2018

ISSN (print) : 1858-4152

ISSN (online) : xxxx-xxxx

Homepage : http://journal.iaimsinjai.ac.id/index.php/al-qalam

sikap dan perilakunya sehari-hari. Dengan kata lain, jiwa islami telah menjadi sumber rujukan dari perilaku seorang muslim sejati dalam hidupnya.

Indonesia sebagai negara yang berfalsafah Pancasila menetapkan tujuan pendidikan adalah untuk meningkatkan ketakwaan terhadap Tuhan Yang Maha Esa, kecerdasan dan ketrampilan, mempertinggi budi pekerti, memperkuat kepribadian dan mempertebal semangat kebangsaan dan cinta tanah air, agar dapat menumbuhkan manusia-manusia pembangun yang dapat membangun dirinya sendiri serta bersama-sama bertanggung jawab atas pembangunan bangsa. ${ }^{22}$

Rumusan tujuan di atas nampak jelas bahwa nilai-nilai yang hendak ditumbuh-kembangkan dalam pribadi anak didik adalah nilai-nilai kultural bangsa Indonesia yang bercorak sosialistis-religius, yaitu semangat kegotong-royongan yang dijiwai oleh nilai keagamaan. Dalam hal ini tidak mengkhususkan nilai agama tertentu. Sedangkan faktor-faktor kognitif, apektif, psikomotorik yang dilandasi dengan moralitas yang tinggi menjadi potensi fundamental bagi perkembangannya dalam hidup bernegara dan berbangsa yang bertanggung jawab. $^{23}$

Hasan Langgulung, berpendapat bahwa nilai akhlak yang perlu dimiliki oleh manusia untuk keselamatan dan kebahagiaan di dunia dan di akhirat. Nilainilai ini dapat dikategorikan dalam lima kategori yaitu:

1. Nilai akhlak perseorangan

2. Nilai akhlak kekeluargaan

3. Nilai akhlak sosial

4. Nilai akhlak kenegaraan

5. Nilai akhlak keagamaan. ${ }^{24}$

Lima nilai di atas intinya adalah takwa. Dengan kata lain takwa itulah himpunan nilai-nilai yang ada dalam Islam. Seperti tergambar dalam QS alBaqarah/2:1-5. Sedangkan menurut Said Agil Husin Almunawar, dengan melihat

\footnotetext{
${ }^{22}$ Armai Arief, Reformulasi Pendidikan Islam (Cet. I; Jakarta: CRSD Press, 2005), h. 19.

${ }^{23}$ Armai Arief, Reformulasi Pendidikan Islam, h. 19.

${ }^{24}$ Hasan Langgulung, Peralihan Paradigma Dalam Pendidikan Islam dan Sains Sosial (Cet. I; Jakarta: Gaya Media Pratama, 2002), h. 101.
} 


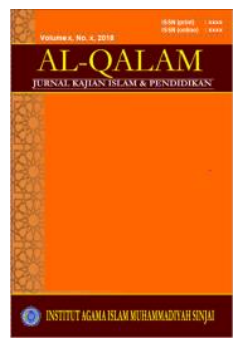

AL-QALAM

Jurnal Kajian Islam \& Pendidikan

Volume 10, No. 2, 2018

ISSN (print) : $1858-4152$

ISSN (online) : 2715-5684

Homepage : http://journal.iaimsinjai.ac.id/index.php/al-qalam

masyarakat yang semakin dinamis sebagai akibat kemajuan ilmu dan teknologi, terutama teknologi informasi, maka aktualisasi nilai-nilai Alquran menjadi sangat penting. Karena tanpa aktualisasi kitab suci ini, umat Islam akan menghadapi kendala dalam upaya internalisasi nilai-nilai Qurani sebagai upaya pembentukan pribadi umat yang beriman, bertakwa, berakhlak mulia, cerdas, maju dan mandiri. Tujuan yang dicapai dalam proses aktualisasi nilai-nilai Alquran dalam pendidikan meliputi tiga dimensi kehidupan yang harus dibina dan dikembangkan oleh pendidikan Islam yaitu: Pertama, dimensi spiritual, yaitu iman, takwa, dan akhlak mulia (yang tercermin dalam ibadah dan muamalah). Kedua, dimensi budaya, yaitu kepribadian yang mantap dan mandiri, tanggung jawab kemasyarakatan dan kebangsaan. Ketiga, dimensi kecerdasan yang membawa kepada kemajuan, yaitu cerdas, kreatif, terampil, disiplin, etos kerja, penghargaan akan waktu, profesional, inovatif dan produktif. ${ }^{25}$

Upaya aktualisasi nilai-nilai Qurani, peran keluarga harus dilakukan, di samping memperkuat lembaga pendidikan formal. Dengan demikian, tanggung jawab akan dipikul bersama oleh guru, orang tua dan masyarakat. Pada intinya, antara tujuan pendidikan Islam dengan nilai-nilai pendidikan Islam harus saling berkaitan dengan erat. Nilai-nilai tersebut merupakan hasil proses kependidikan yang diinginkan, namun yang paling penting dalam proses kependidikan ini adalah, nilai yang oleh setiap orang diusahakan secara sungguh-sungguh untuk merealisasikannya melalui pendidikan. Nilai-nilai itu adalah yang terwujud di dalam keseluruhan hidup pribadi dan sosial manusia. Nilai-nilai yang mampu mempengaruhi, memberi corak dan watak kepribadian yang berkembang sepanjang hayatnya.

Seluruh nilai-nilai pengajaran agama itu bermuara pada nilai hakiki atau nilai esensial yang berbentuk, yaitu:

\footnotetext{
${ }^{25}$ Said Agil Husin Almunawar, Aktualisasi Nilai-Nilai Qurani dalam Sistem Pendidikan, h. $6-7$.
} 


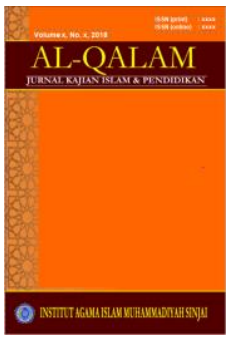

1. Nilai pembersihan atau pensucian rohani/jiwa, yang memungkinkan seseorang siap untuk menerima, memahami dan menghayati ajaran agama Islam sebagai pandangan hidupnya.

2. Nilai kesempurnaan akhlak, yang memungkinkan seseorang memiliki alakhlāq al-karimmah, yang tercermin pada sifat-sifat Nabi Muhammad saw. dan mengamalkannya ajaran agama Islam secara sempurna sepanjang hayatnya.

3. Nilai peningkatan taqwa kepada Allah swt, sehingga diri seseorang menjadi semakin akrab kepadanya dan dengan penuh gairah serta ketulusan hati menyongsong kehidupan yang hakiki. ${ }^{26}$

Dengan demikian, dalam pendidikan Islam nilai yang perlu diwariskan itu tidak lain adalah nilai-nilai yang terdapat dalam sumber ajaran Islam, yakni Alquran dan sunnah. Nilai-nilai tersebut mencakup aspek kepribadian manusia sebagai individu dan sebagai anggota masyarakat. Oleh karena itu, nilai-nilai yang berkembang dalam masyarakat sepanjang tidak bertentangan dengan semangat ajaran Islam adalah termasuk nilai-nilai budaya yang perlu dilestarikan. Dan inti dari nilai-nilai itu sebenarnya tersimpul dalam al-akhlāq al-karīmah. ${ }^{27}$

Ahklak mulia merupakan muara dari segenap aktivitas pendidikan, maka pelajaran yang diberikan dalam bentuk apapun, baik pengajaran ilmu pengetahuan, pelatihan keterampilan/keahlian tertentu, maupun bimbinganbimbingan mental kerohanian (apektif).

Pencapaian dari salah satu unsur manapun yang menonjol dari potensi anak didik itu harus bermuatan budi pekerti. Budi pekerti sebenarnya merupakan suatu konsep nilai yang abstrak. Penampakannya hanya ada dalam seluruh gerak motorik dan ekspresi apektif dan kognitif seseorang. Dengan kata lain, budi pekerti seseorang hanya dapat diketahui bilamana seorang itu melakukan interaksi dengan lingkungannya, baik lingkungan pisik-material maupun lingkungan sosial.

\footnotetext{
${ }^{26}$ Said Agil Husin Almunawar, Aktualisasi Nilai-Nilai Qurani dalam Sistem Pendidikan, h. 196.

${ }^{27}$ Muhammad Athiyah al-Abrasyi, al-Tarbiyah al-Islamiyah, Terjemahan Bustami A. Gani dan Djohar Bahry, Dasar-Dasar Pokok Pendidikan Islam (Cet. VII; Jakarta: Bulan Bintang, 1993), h. 1 .
} 


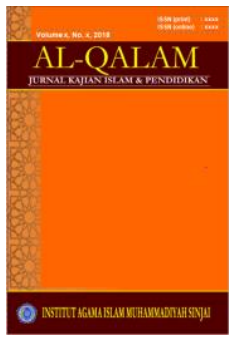

\section{KESIMPULAN}

Nilai dan budaya yang perlu diwariskan dalam pendidikan Islam itu tidak lain adalah nilai-nilai yang terdapat dalam sumber ajaran Islam, yakni Alquran dan sunnah. Nilai-nilai tersebut mencakup aspek kepribadian manusia sebagai individu dan sebagai anggota masyarakat. Oleh karena itu, nilai-nilai yang berkembang dalam masyarakat sepanjang tidak bertentangan dengan semangat ajaran Islam adalah termasuk nilai-nilai budaya yang perlu dilestarikan. Inti dari nilai-nilai itu sebenarnya tersimpul dalam al-akhlāq al-karìmah.

\section{DAFTAR PUSTAKA}

A. Baki, Nasir. Filsafat Pendidikan Islam. Cet. I; Makassar: Alauddin University Press, 2013.

Al-Abrasyi, Muhammad Athiyah. al-Tarbiyah al-Islamiyah. Diterjemahan oleh Bustami A. Gani dan Djohar Bahry dengan judul Dasar-Dasar Pokok Pendidikan Islam. Cet. VII; Jakarta: BulanBintang, 1993.

Al-Munawar, Said Agil Husin. Aktualisasi Nilai-Nilai Qurani dalam Sistem Pendidikan Islam. Cet. I; Jakarta: Ciputat Press, 2003.

Arief, Armai. Reformulasi PendidikanIslam. Cet. I; Jakarta: CRSD Press, 2005

Arifin,M. Filsafat Pendidikan Islam. Cet. IV; Jakarta: BumiAksara, 1994.

Bagus, Lorenz. Kamus Filsafat. Cet. III; Jakarta: Gramedia, 2002.

B. F. Skinner, Science and Behavior, Terjemah Maufur, Ilmu Pengetahuan dan Perilaku Manusia (Cet. I; Yogyakarta: Pustaka Belajar, 2013.

Daradjat, Zakiah. Metodik Khusus Pengajaran Agama Islam. Cet. III; Jakarta: Bumi Aksara, 2004.

Departemen Agama RI, Al-Qur'an dan Terjemahannya. Bandung: CV. J-ART, 2005.

Faisal,Jusuf Amir. Reorientasi Pendidikan Islam.Cet. I; Jakarta: Gema Insani Pres, 1995.

Gazalba, Sidi. Asas Kebudayaan Islam Pembahasan Ilmu dan Filsafat Tentang Ijtihad, Fiqih, Akhlak, Bidang-bidang Kebudayaan, Masyarakat, Negara. Cet. I; Jakarta: Bulan Bintang, 1978.

Getteng, Abd. Rahman. Pendidikan Islam dalam Pembangunan Moral, Remaja, Wanita, dan Pembangunan. Makassar: Yayasan Al-Ahkam, 1997. 


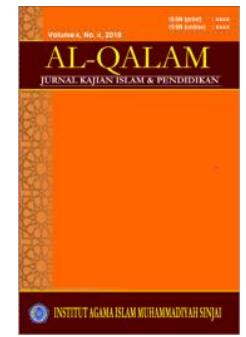

AL-QALAM

Jurnal Kajian Islam \& Pendidikan

Volume 10, No. 1, 2018

ISSN (print) : 1858-4152

ISSN (online) : xxxx-xxxx

Homepage : http://journal.iaimsinjai.ac.id/index.php/al-qalam

Khaeruddin. Pemikiran Nilaidan Etika Pendidikan Islam. Cet. I; Makassar: Yayasan Pendidikan Makassar, 2003.

Langgulung, Hasan. Asas-Asas Pendidikan Islam. Cet. II; Jakarta: Pustaka AlHusna, 1992.

.Pendidikan Islam Menghadapi Abad Ke 21. Cet. I; Jakarta: Pustaka AlHusna, 1988.

.Peralihan Paradigma DalamPendidikan Islam dan Sains Sosial. Cet. I; Jakarta: Gaya Media Pratama, 2002.

Mudyaharjo, Redja. Pengantar Pendidikan, Sebuah Studi Awal tentang DasarDasar Pendidikan pada Umumnya dan Pendidikan di Indonesia. Cet.I; Jakarta: Raja Grafindo Persada, 2001.

Mulyana, Rohmat. MengartikulasikanPendidikanNilai.Cet. I: Bandung: Alfabeta, 2004.

Nottingham, Elizabeth K. Agama dan Masyarakat; Suatu Pengantar sosiologi Agama Ed. I. Cet. IIX; Jakarta: PT RajaGrafindo Persada, 2002.

Poerbawatja, Soegarda. Ensiklopedi Pendidikan. Jakarta: Gunung Agung, 1999.

Qutb, Muhammad. Sistem Pendidikan Islam. Cet. I; bandung: PT. Al-Ma'arif, 1984.

Redaksi Ensiklopedi Nasional. Ensiklopedi Nasional Indonesia. Jilid III. Cet. I; Jakarta: PT. CiptaAdiPustaka, 1988.

Surajiyo, Filsafat Ilmu dan Perkembangannya di Indonesia: Suatu Pengantar. Cet VII; Jakarta: Bumi Aksara, 2013.

Tafsir,Ahmad. Ilmu Pendidikan dalam Islam Perspektif Islam. Cet. I; Bandung: Remaja Rosdakarya, 1992.

Tilaar, H.A.R. Paradigma Baru Pendidikan Nasional. Cet. II; Jakarta: RinekaCipta, 2004.

Tim Penyusun Kamus Pusat Bahasa. Kamus Besar Bahasa Indonesia. Cet. III; Jakarta: Balai Pustaka, 2005.

O’Neill F, William. Educational Ideologies, Terjemah Omi Intan Naomi, IdiologiIdiologi Pendidikan. Cet. II; Yogyakarta: Pustaka Belajar, 2008. 